\title{
The Market for Paintings in Italy During the Seventeenth Century
}

\author{
FEDERICO ETRO AND LAURA PAGANI
}

We study the seventeenth-century market for figurative paintings in Italy analyzing original contracts between patrons and artists. We show that a number of supply and demand factors affected prices. We find a positive and concave relation between prices and size of paintings reflecting economies of scale. We show evidence of a positive relationship between prices and the number of figures depicted. Trade in paintings was sufficient to equalize prices between different destinations. Finally, we provide support for the Galenson hypothesis of a positive relation between age of experimental artists and quality as priced by the market.

\begin{abstract}
$A$ wide economic history literature has analyzed preindustrial markets $\mathbf{A}_{\text {to find evidence of the basic laws of economics. Given the limited }}$ amount of data available on this period, most studies have focused on the aggregate fluctuations of prices and quantities in agriculture and on international trade of commodities. ${ }^{1}$ Direct evidence on equilibrium prices and contracts in the preindustrial manufacturing sector is more elusive because information on sellers, buyers and the goods rarely survived. A remarkable exception is the market for paintings: here we still have wide information about the sellers (the artists), that have been the subject of research and analysis in art history, about the buyers (the patrons), whose documentary evidence, including contracts and payments' notes, often survived until today, and about the goods (the paintings), that oftentimes are still visible in their original locations or in public and private collections.
\end{abstract}

The Journal of Economic History, Vol. 72, No. 2 (June 2012). (C) The Economic History Association. All rights reserved.

Federico Etro is Professor, University of Venice, Ca' Foscari, Dipartimento di Economia, Cannaregio 873, 30121 Venice, Italy. E-mail: federico.etro@unive.it. Laura Pagani is Assistant Professor, University of Milan Bicocca, Dipartimento di Economia Politica, Piazza Ateneo Nuovo, 1, 20126 Milan, Italy. E-mail: laura.pagani@unimib.it.

We are thankful to Silvia Marchesi, Deirdre McCloskey, Luca Mocarelli, Piergiovanna Natale, Laura Onofri, Luciano Pezzolo, Giuseppe Tattara, Paolo Tedeschi, Valerio Varini, and two anonymous referees for helpful suggestions and David Galenson, Philip Sohm and Richard Spear for encouraging comments. We are especially indebted to Jean-Laurent Rosenthal for valuable comments and suggestions. The Gabinetto di Numismatica of the Sforza Castle of Milan provided significant help on monetary issues.

${ }^{1}$ Among others, see McCloskey and Nash, "Corn at Interest"; Clark, "Cost of Capital"; O'Rourke and Williamson, Globalization and History; and Rönnback, "Integration of Global Commodity." 
We analyze the Baroque market for figurative paintings in Italy to find evidence of the laws of demand and supply and of the rational behavior of agents. Evidence in such a market is important because this is an extreme example of a market in which we may expect that rationality plays a minor role: art objects are often perceived, and sometimes defined, as handmade works that are valuable independently of their objective features and as the fruit of pure talent and inspiration independently from monetary and contractual incentives. At the same time, the pricing of a unique art object is often perceived as highly subjective and largely dependent on the tastes, wealth, and prestige of buyers, with little regard for factors affecting demand and supply, especially when one is thinking of the seventeenth century, in which honor and prestige were claimed to be the drivers of social and economic activities more than the profit-seeking behavior of the homo economicus. Our purpose is to show that these perceptions are largely misleading.

The analysis is built around a new unique data set on original contracts between patrons and painters based on the recent monumental research by Richard E. Spear and Philip L. Sohm. ${ }^{2}$ We focus on commissions for large oil paintings of figurative (religious or mythological) subject, produced in the main Italian art centers (Venice, Rome, Florence, Bologna, and Naples) in the seventeenth century, and we investigate the relationship between the price of paintings and a number of variables characterizing the same paintings, the painters, the patrons and the macroeconomic context.

The equilibrium prices in this market can reflect the expected aesthetic value of the paintings, which is mostly dependent on artist's style. They are thus hedonic prices. Beyond this, we show that a number of supply and demand factors affect value: for instance, we find a positive and concave relation between prices and size of paintings reflecting economies of scale in the production of paintings.

More interestingly, we provide evidence of contractual solutions to moral hazard problems between patrons (principals) and artists (agents). Large commissions for oil paintings of figurative subject required months or years of work and generated conflicts of interest for the simple reason that quality required time and effort, but was neither negotiable ex ante nor measurable ex post. ${ }^{3}$ We provide evidence that patrons and artists most often adopted a solution to the moral hazard problem pointed out in the literature on principal-agent contracts ${ }^{4}$ :

\footnotetext{
${ }^{2}$ Spear and Sohm, Painting for Profit.

${ }^{3}$ See Nelson and Zeckhauser, Patron's Payoff.

${ }^{4}$ Holmstrom, "Moral Hazard."
} 
prices were made conditional on measurable features of the paintings which were positively correlated with effort and quality, the main one being the number of human figures depicted in the composition (for given size and painters' features).

Moving from microeconomic aspects to macroeconomic ones, we evaluate the impact of local demand shocks. Differences in local demand could be detected when looking at different destinations: demand was higher in larger and richer cities such as Rome compared to smaller provincial towns in the countryside. In spite of this, we show that there was sufficient trade in paintings to equalize prices: although prices in the countryside were lower, after controlling for paintings' and painters' features, this price differential disappears.

Finally, we provide novel support for the Galenson hypothesis ${ }^{5}$ concerning the life cycle of the painters: experimental innovators (exemplified by Titian, Tintoretto, Domenichino, or Guido Reni) increased gradually the quality of their work (as priced by the market) while aging and improving their technique with experience, whereas conceptual innovators (exemplified by Caravaggio) did not appear to exhibit a positive correlation between quality (prices) and age.

As far as we know, this is the first work to test theoretical predictions for the art market on data from original contracts between artists and patrons. However, our analysis is related to two strands of literature. The first analyzes the impact of economic factors on the art market. There is a long tradition in art critique regarding the relation between social and artistic developments ${ }^{6}$, but only recently economists such as Neil De Marchi and John M. Montias and economic historians such as Michael North have emphasized the importance of economic incentives in shaping the Dutch art market of the seventeenth century. ${ }^{7}$ Michelle O'Malley and Jonathan K. Nelson and Richard Zeckhauser have provided the first studies of the art contracts during the Italian Renaissance. ${ }^{8}$ Spear and Sohm have extended the analysis to the subsequent Baroque period, deriving an interesting analysis of the economic lives and incomes of the painters. ${ }^{9}$ However, the key contribution of these works is data collection because, although they provide a fine descriptive analysis, they do not carry out econometric investigations or test economic hypotheses. ${ }^{10}$

\footnotetext{
${ }^{5}$ See Galenson and Weinberg, "Age and the Quality”; and Galenson, Old Masters.

${ }^{6}$ See Hauser, Social History.

${ }^{7}$ De Marchi, "Role of Dutch Auctions"; Montias, Art in Auction; and North, Art and Commerce.

${ }^{8}$ O'Malley, Business of Art; and Nelson and Zeckhauser, Patron's Payoff.

${ }^{9}$ Spear and Sohm, Painting for Profit.

${ }^{10}$ The only related multivariate analysis we are aware of is by Gérin-Jean, "Prices of Works of Art," who investigated the determinants of the prices of heterogeneous artworks, including
} 
The second relevant literature was started with the works by David W. Galenson on the relation between age and artistic innovations. ${ }^{11}$ Most of the econometric evidence in support of the Galenson hypothesis relative to the different age profiles of quality production for experimental and conceptual innovators is based on data from modern auctions for modern art. $^{12}$ Our study allows us to evaluate the Galenson hypothesis for old master painters looking at the relation between their age and the aesthetic value of their work as perceived and priced at their time.

\section{THE MARKET FOR OIL PAINTINGS}

From the Renaissance to the end of the early modern period, a large part of the Italian urban wealth was channeled toward durable goods with artistic content, from architecture (palaces, villas, churches. . .) to sculpture and other decorative elements including, of course, altarpieces and other paintings. ${ }^{13}$ By the seventeenth century, the Italian market for paintings was characterized by a wide product differentiation: while most paintings from the previous centuries were figurative (mainly of religious, historical, or mythological subject), the raising demand from private buyers induced the production of new subjects (as landscapes, genre paintings, and still lifes beside portraits and battles. . .). Only the best painters were engaged in traditional paintings, especially altarpieces, ${ }^{14}$ whose more ambitious compositions could include many interacting human figures. ${ }^{15}$

The market for oil paintings involved a form of price competition among painters. In the main art centers, as Rome, Florence, and Venice, artists were organized in guilds or academies that charged entry fees. A member of the guild could invest to open his own workshop and employ assistants to sell paintings under rules established by the guild.

statues, decorative objects, and also paintings of any subject, from inventories (and not original contracts) of the Medici period, mainly with predictive and ranking purposes. However, the procedure used for converting prices into a unique currency and the adjustment for inflation (using an index computed for England) appear inaccurate.

${ }^{11}$ Galenson, Old Masters.

${ }^{12}$ Galenson and Weinberg, "Age and the Quality"; and Hellmanzik, "Location Matters."

${ }^{13}$ Goldthwaite, Wealth and the Demand.

${ }^{14}$ Painted altarpieces had a long-standing tradition in Italy. Initially, different kinds of altarpieces coexisted, with at one extreme polyptychs on wood panels with multiple surfaces painted with expensive colors (gold and ultramarine blue, usually paid by the patrons) and surrounded by expensive carved and gilded frames, and at the other extreme simple rectangular canvases prepared without golden backgrounds and frames. By the mid-sixteenth century and for the following two centuries, the latter typology of altarpieces, and its minor variations for wall and ceiling decorations, became a rather common product whose market is the subject of our study.

${ }^{15}$ Spear and Sohm, Painting for Profit. 
However, these guilds were not very effective at protecting the rents of their members. ${ }^{16}$ First, some low-quality or foreign artists did not join the guilds and sold their paintings without following the basic rules decided by the guild. Second, price competition was strong, with painters undercutting each other, adopting different forms of price discrimination, ${ }^{17}$ and heavily advertising their works.

Artists were extremely mobile. Italian and foreign artists could easily travel between the main art centers, ${ }^{18}$ and painters could receive commissions from distant locations, paint in their own workshop, and send the finished products to the final destination (especially when canvases replaced wood panels as support). Transport costs were low, and tariffs when in place were low enough not to constrain trade. Patrons were willing to hire painters from any provenance as long as they satisfied their tastes. ${ }^{19}$ Notice that there were substantial differences between the Venetian style (emphasizing colore) and the Central Italian style (emphasizing disegno) as pointed out by the art critic Vasari. Therefore, taking into account the mobility of painters and the differences in artistic style, one might conjecture that there were two highly integrated markets, one in the North around Venice and the other in Central Italy that included Rome, Bologna, Florence, and Naples. For this reason, we will analyze them separately.

Large oil paintings required months or even years to complete, even though artists typically worked on several pieces at once with the help of assistants. Most commissions for figurative paintings were formalized in notarized contracts. These contracts, which were enforceable throughout Italy, stipulated the price and the responsibilities of the patron and of the artist. ${ }^{20}$ Of course, these contracts were largely incomplete because the main issue, the quality of the paintings, could be observed by the buyer, but it could be neither defined ex ante nor verified ex post. ${ }^{21}$

\footnotetext{
${ }^{16}$ Favaro, Arte dei Pittori.

${ }^{17}$ Painters often adopted quantity discounts to obtain multiple commissions. There is also evidence of different quality levels made available for different prices: Luca Giordano said he could paint with three brushes for different prices: a gold brush, a silver one, and a bronze one (for this reason, he was called Luca fa' presto, literally "Luca does it quickly").

${ }^{18}$ There is wide and clear evidence for this. Venice had a long tradition for receiving North European artists (at least since the arrival of Durer), and Rome started attracting foreign painters since early Renaissance. During the seventeenth century, Venice imported many foreign artists (such as Heintz, Loth, and Strozzi) and also temporarily exported others (such as Ricci or Pellegrini), while Rome was the leading international center for artists from all of Europe.

${ }^{19}$ Spear and Sohm, Painting for Profit.

${ }^{20}$ O'Malley, Business of Art.

${ }^{21}$ See also Nelson and Zeckhauser, Patron's Payoff.
} 


\section{THE PRICE OF PAINTINGS}

The price of paintings depended on a variety of factors; these can be divided into those that reflect supply features, those that reflect demand features and those that relate to the incompleteness of the contracts. On the first level, prices should increase with the size of paintings, but in a less than proportional way because of likely economies of scale (any painting would require some time for thinking about the composition and for working on preparatory sketches independently from its size). Another obvious determinant of the price of a painting is the expected quality supplied by each painter, which translates in the aesthetic value as perceived by the contemporary audience: average prices clearly differ across painters.

Other important elements of a commission for a painting were related to the demand side. A crucial factor was the type of the buyers: differences in their willingness to pay may have affected the contracts in place and through them the prices. ${ }^{22}$ Another factor is the final position of the painting: the hierarchy of spaces within churches and buildings and the substitutability with competing decorations could affect the willingness to pay and therefore the prices. Finally, multiple commissions may have commanded lower unitary prices as a form of quantity discounts.

There are no deep artistic reasons for making prices depend on the number of human figures in a painting (after controlling for size). ${ }^{23}$ Spear and Sohm do not find wide contractual evidence of an explicit impact of the number of figures on prices. ${ }^{24}$ However, prices may have been decided on the basis of the number of figures in verbal agreements or separate notes, and from an economic point of view there could be an efficient rationale for the adoption of prices increasing in the number of figures.

\footnotetext{
${ }^{22}$ For instance, in some cases a sort of efficiency wage mechanism may have taken place for some commissions. Some public patrons were available to pay more than others to induce extra effort for their occasional commissions, and the artists employed by them were available to exert this extra effort to obtain additional commissions and avoid going back to the ordinary market-where these efficiency wage mechanisms were absent. The same mechanisms were likely to be at work in the case of the occasional altarpieces directly commissioned by the popes for St. Peter's Church (popes had both spiritual and temporal power at the time and, hence, they had vast resources to invest in sacred art).

${ }^{23}$ In letter of 1667 , the painter Cortona addressed to a commissioner criticizing a positive relation between number of figures and price: "Others say that the space between one figure and another are a weakness, [which] shows a lack of understanding of painting because sometimes those spaces are necessary for artistic reasons, as the petitioner has done, and not to save labor" (see Spear and Sohm Painting for Profit, for further discussion).

${ }^{24}$ Ibid.
} 
More specifically, the patrons' payoff from a contract for a painting could be seen as the difference between the benefits obtained with the commission and the price paid to the artist. The benefits of the patrons were in terms of display of what was called "magnificence" in front of the contemporary audience, of the high-class elite and, in case of altarpieces, even in front of God. ${ }^{25}$ Clearly, the signaling benefits from these ostentatious commissions were positively related to the quality of the artworks. Hence, patrons cared for quality.

However, since quality was not directly negotiable (and verifiable) and it required also costly effort for the painter, moral hazard was a relevant issue in the artist-patron relationship, and patrons had to find ways to obtain high-quality artworks. The solution could be to include in the contract some verifiable and measurable feature of the painting correlated with effort and quality (according to the informativeness principle first stated by Bengt Holmstrom ${ }^{26}$ ).

A potential candidate for this was the number of human figures. This was not equivalent to the absolute quality of a painting, but was correlated with it for at least three main reasons. First of all, the subjects of the commissioned paintings were biblical or mythological stories where the variety and complexity of the composition, summarized by the number of players, had a positive, though partial, correlation with effort and final quality. Second, at the time there was a precise ranking in the aesthetic evaluation of subjects (genres), with figurative compositions at the top and landscapes, genre paintings, and still lifes in decreasing order of appreciation. A higher number of human figures was reducing on average the space available for subjects of lower perceived quality, as background landscapes or decorative still lifes, and this was automatically enhancing overall quality. Third, painters were often focusing their own effort on human figures and especially on difficult parts as the heads (where their own style was more easily recognized), delegating less relevant parts (including background decorations, landscapes, and still lifes) to their own assistants. Accordingly, a higher number of figures was a proxy for a wider direct intervention of the main painter in the overall execution, and consequently for higher quality.

However, if it can be taken as given that the number of figures affected quality positively, painting human figures required time and

\footnotetext{
${ }^{25}$ See Nelson and Zeckhauser, Patron's Payoff. In particular, for the private patrons, showing wealth and status through these commissions was extremely useful for business and for the political and ecclesiastical careers (all being strongly interrelated at the time), and showing devotion was useful to conquer a place in heaven.

${ }^{26}$ Holmstrom, "Moral Hazard."
} 
was costly for the painter. Hence, from an economic point of view, making the price of a painting depending on the number of human figures could be seen as a way for patrons to enhance quality by paying indirectly for it. $^{27}$

Indeed, there is evidence that even when a price per figure was not explicitly stated in the contracts, further agreements on the number of figures may have been established in separate notes, letters, or even verbal communications. ${ }^{28}$ Most important, we know that pricing by number of figures became a typical procedure during the early seventeenth century in the city of Bologna, where the leading painters Guercino and Guido Reni were able to maintain their high fees justifying them with a commitment to a high price per figure (again, rarely written in contracts but implicitly recognized in many agreements). ${ }^{29}$

Finally, let us consider price differences between different destinations. According to Spear and Sohm, anecdotal evidence on the higher prices in richer cities is confirmed by the data on average prices for Venice and minor Venetian towns between the second half of the sixteenth century and the beginning of the eighteenth century. ${ }^{30}$ Similar anecdotal evidence emerges for price differentials between Rome and other Italian towns. ${ }^{31}$ The common view is that this phenomenon was general: large cities were perceived as paying better their commissions and Rome better than all the other cities. However, the high mobility of painters suggests that we should be suspicious of this point of view. Indeed, high price differentials should have induced small town painters either to migrate to large urban centers, or to sell their art there. In any

\footnotetext{
${ }^{27}$ To induce effort other contractual solutions were adopted as well. First of all, many contracts required preliminary drawings to be evaluated and possibly approved by the patrons. Second, ex post rejection of the painting in case of low quality was a credible threat for the artists. However, both these practices could only insure a minimum level of effort. Third, contracts occasionally left space for bonuses for quality between 10 percent and 20 percent (O'Malley, Business of Art, p. 125): judgment was sometimes by the patrons and other times by other painters, inducing conflicts of interests in both cases. The last practice may be seen as a sort of incentive contract, but its effectiveness appears limited.

${ }^{28}$ For instance, this happened in one of the rare epistolary negotiations survived until our days and involving the Venetians painters Liberi and Zanchi (see Spear and Sohm, Painting for Profit, pp. 13-15).

${ }^{29}$ Apparently, Guercino was an extreme example, because he claimed to commit to a fixed price of 100 scudi per full-length figure (50 for half-length figure, 25 for heads). In a letter of 1628, Guido Reni argued that low-level painters could not obtain more than two or three scudi for large life-size figures and ordinary painters could ask at most 15 scudi per figure, while an extraordinary painter like himself could name his own price on the basis of the quality of his work independently from size and number of figures. This was probably a selling technique, but it may have reflected a way of thinking about the relation between prices and the number of figures.

${ }^{30}$ Spear and Sohm, Painting for Profit, pp. 234-35.

${ }^{31}$ Ibid., p. 233.
} 
case, mobility should have led prices of similar paintings in different locations to converge. Given the high mobility of painters and paintings, we expect prices to have been similar throughout an integrated region as the Venetian Republic or as Central Italy.

\section{THE AGE OF PAINTERS AND THE LIFE CYCLE OF ARTISTIC CREATIVITY}

During the seventeenth century, paintings of figurative subject were the most important segment of the market for paintings and commissions were given only to artists whose reputation and value was already established. This implies that any learning about the quality of these painters had already occurred before they began to receive these important commissions (or that it was actually a precondition). Nevertheless, the experience of a painter, and his age as a proxy for it, could still affect the quality (and price) of his paintings, at least for an ideal category of artists that Galenson has defined as experimental innovators. ${ }^{32}$ These are painters able to develop a gradual and continuous path of experimentation and change during their career. In Galenson's view, the quality of the art of experimental innovators, as appreciated by experts and priced by the market, keeps improving with age. As a result, the life-cycle profile for the quality (and price) of their works should reach a peak at a very advanced age. According to Galenson and Jensen, leading examples of experimental innovators have been Michelangelo, Titian, and Rembrandt, ${ }^{33}$ but other examples of these step-by-step innovators may have been Tintoretto, Reni, Domenichino, and Ricci.

The opposite category of artist identified by Galenson ${ }^{34}$ is that of conceptual innovators, who produce path breaking innovations by applying a radically different perspective on the same artistic problem. Galenson argues that conceptual innovators tend to produce their most important work at a young age, and therefore they should not exhibit a significant relation between age and quality as priced by the market (or, at least, they should reach a peak at a very young age). Galenson and Jensen propose the examples of Masaccio in the fifteenth century and Raphael in the sixteenth century, ${ }^{35}$ but the most prominent example may actually be Caravaggio in the seventeenth century.

\footnotetext{
${ }^{32}$ Galenson, Old Masters.

${ }^{33}$ Galenson and Jensen, "Young Geniuses." Here innovations are not defined as absolute improvements per se: they are simply changes that are appreciated by the contemporary audience and that, if markets are properly working, are also better paid.

${ }^{34}$ Galenson, Old Masters.

${ }^{35}$ Galenson and Jensen, "Young Geniuses."
} 
Galenson and Jensen ${ }^{36}$ and Galenson ${ }^{37}$ test empirically these hypotheses with recent auction prices for modern painters but they did not do so for the old masters. Our data allow us to analyze the life cycle of artistic creativity for painters of the Baroque age. ${ }^{38}$ Given the coexistence of both kinds of artists, on average we expect a positive or inverted U-shaped relation between age and quality. Moreover, we can also examine examples of different kinds of innovators.

\section{THE MARKET IN THE VENETIAN REPUBLIC}

In this section, we focus on the market for paintings produced in the Venetian Republic, which we take to be integrated and for which we have access to very detailed information. The main source of the data is the monumental work of Spear and Sohm, ${ }^{39}$ who have collected information on 254 oil paintings completed between 1551 and 1746 by 61 artists of any provenance active in the Venetian Republic. Spear and Sohm's culled original contracts and other documentary evidence to assemble information on commission prices, all converted in silver ducats, and on other characteristics of these paintings. Their sample is representative of the (many more) commissions for oil paintings of high quality that took place at the time. In fact, one should keep in mind that the data set select paintings by artists whose reputation was good enough to get commissions from important patrons; in other words, the fringe of minor (and today mostly anonymous) painters engaged in minor commissions and genres is absent.

Complementing other art history sources to the Spear and Sohm data set, we obtained the following information for each painting: title, author, size of the painting, number of figures included in the composition (counting partially the half-length figures and the heads), position of the painting in the building (in other words on a main or secondary altar, on the ceiling, or on lateral walls including the organ), patron's type (church, public authority, or private collector), date of commission and age of the artist when the painting was made. We also built variables indicating whether the painting belonged to a commission of multiple works, the town of destination and the perceived quality of the painters (proxied by the artists' fixed effects).

\footnotetext{
${ }^{36}$ Ibid.

${ }^{37}$ Galenson, Old Masters.

${ }^{38}$ Art history research on old master paintings has not advanced a systematic investigation of the relation between age and artistic innovations, and even less between age and monetary compensation in the market. Only some anecdotal evidence is available and by no means conclusive (for instance, Spear and Sohm, Painting for Profit, p. 28).

${ }^{39}$ Spear and Sohm, Painting for Profit.
} 
TABLE 1 SUMMARY STATISTICS: VENETIAN REPUBLIC

\begin{tabular}{lrrrc}
\hline \hline & & & & \\
Variables & Mean & Std. Dev. & Min. & Max. \\
\hline Price (silver scudi) & 193.50 & 245.83 & 5 & 2,306 \\
Size (sq. meters) & 12.42 & 14.15 & 0.4 & 84.8 \\
No. of figures & 9.77 & 9.40 & 1 & 59 \\
Altar & 0.41 & 0.49 & 0 & 1 \\
Wall & 0.48 & 0.50 & 0 & 1 \\
Ceiling & 0.11 & 0.32 & 0 & 1 \\
Venice & 0.41 & 0.49 & 0 & 1 \\
Minor destination & 0.22 & 0.42 & 0 & 1 \\
Verona/Vicenza & 0.15 & 0.36 & 0 & 1 \\
Bergamo & 0.05 & 0.22 & 0 & 1 \\
Padua & 0.04 & 0.20 & 0 & 1 \\
Treviso & 0.03 & 0.17 & 0 & 1 \\
Exports & 0.10 & 0.30 & 0 & 1 \\
Religious commissioner & 0.75 & 0.43 & 0 & 1 \\
Age (years) & 52.22 & 13.61 & 22 & 81 \\
\hline
\end{tabular}

Sources: Own elaboration on Spear and Sohm data.

Table 1 shows a list of the variables we used in the empirical analysis together with their main summary statistics. The average painting had a price of 193.5 Venetian silver ducats, was more than 12 square meters large, and contained almost ten figures. Threequarters of the commissions were for religious institutions. Of these, 41 percent decorated an altar, 48 percent walls, and 11 percent ceilings. Only 41 percent of the artworks in our sample were intended to be placed in Venice, the rest elsewhere in the Venetian Republic including Verona and Vicenza (overall 15 percent), Bergamo (5 percent), Padua (4 percent), and Treviso (3 percent). Almost one-fifth of the paintings were to be sent to small provincial towns (for instance, Castelfranco Veneto, Trevenzolo, Lentiai, Salò. . .). Finally, about 10 percent of the paintings were exported, but mostly to other Northern Italian towns as Turin, Milan, and Genoa or outside Italy. The average age at which artworks were made in Venice was above fifty. ${ }^{40}$

\footnotetext{
${ }^{40}$ The average age is very high for the living standards of that time. This may reflect the importance of the commissions to which the observations in our data set refer: most painters started their careers as assistants to their masters, preparing minor works or even copying others' paintings, and only after a few years they started receiving commissions from churches and other important patrons. Of course, the late average age may also reflect the relatively good living conditions of the painters. Note that despite the high average age, the range of variation is high as well, which allows us to estimate the age-price profile.
} 
To examine the value of commissions for old masters' paintings in the Venetian Republic during the Baroque period, we follow the hedonic price literature, and regress the natural logarithm of the price of these paintings on a set of paintings' and artists' characteristics. ${ }^{41}$ The explanatory variables include the size of the painting and its number of figures. Squared size is also considered in order to test for economies of scale. Moreover, we include a set of indicator variables for the paintings' ultimate placement, for the type of patron, and for the final destination. Another regressor is the age of artists when the work was produced. In order to take into account of changes in the Venetian art market in the period under analysis, we insert among explanatory variables the year in which the painting was executed, whose coefficient represents the time trend.

Table 2 shows OLS estimates of the price equation. Let us focus on column 3 which includes the full set of regressors. The $R^{2}$ is equal to 77.4 percent, pointing out a good overall fit and providing first evidence of the existence of a systematic pattern in the process of price determination. ${ }^{42}$ Not surprisingly, larger paintings were more expensive: we find a premium of about 9 percent per square meter. Additionally, the negative and significant coefficient of squared size suggests that there were some scale economies over the range of painting's size. Each figure brought an increase in a painting's price of around 3 percent (we did not find indications of decreasing return to figures). As argued before, human figures were positively correlated to quality, but painting human figures was costly for the painter. Hence, from an economic point of view, making the price of a painting depending on the number of human figures was a way for patrons to enhance quality by paying indirectly for it.

Paintings' price also reflected where they were planned to be placed. Artworks produced for wall decorations in churches were paid much less than altarpieces. A potential explanation for this result is that a large number of substitutes for decorating lateral walls existed

\footnotetext{
${ }^{41}$ Painting prices were negotiated in Venetian silver ducats. During the seventeenth century, inflation was limited, but sustained in the sixteenth (due to the central European silver mining boom and to the import of American silver). Prices were very variable in the first half of the eighteenth century. To take into account of changes in the price level, a temporal trend is included in the regression. See Etro and Pagani, Market for Paintings, for additional analysis based on prices corrected for the cost of living.

${ }^{42}$ Notice that paintings' characteristics matter a lot as witnessed by the large increase in the $R^{2}$ moving from column 1 (that does not include paintings' characteristics) to column 2 (including paintings' characteristics).
} 
TABLE 2

OLS REGRESSION: VENETIAN REPUBLIC Dependent variable: $\ln$ (price)

\begin{tabular}{|c|c|c|c|c|c|c|}
\hline Independent Variables & $(1)$ & & (2) & & (3) & \\
\hline \multicolumn{7}{|c|}{ PAINTINGS' CHARACTERISTICS } \\
\hline Size (sq. meters) & $0.033 * * *$ & $(0.007)$ & $0.105 * * *$ & $(0.009)$ & $0.095 * * *$ & $(0.010)$ \\
\hline Squared size & & & $-0.001 * * *$ & $(0.000)$ & $-0.001 * * *$ & $(0.000)$ \\
\hline No. of figures & & & $0.034 * * *$ & $(0.005)$ & $0.029 * * *$ & $(0.005)$ \\
\hline Wall * church & & & $-0.864 * * *$ & $(0.132)$ & $-0.712 * * *$ & $(0.130)$ \\
\hline Ceiling * church & & & $-0.440 *$ & $(0.224)$ & -0.330 & $(0.232)$ \\
\hline Secular commissioner & & & $-0.269 * *$ & $(0.115)$ & -0.116 & $(0.126)$ \\
\hline Minor destination & $-0.291 *$ & $(0.168)$ & $-0.290 * *$ & $(0.131)$ & -0.200 & $(0.133)$ \\
\hline Verona/Vicenza & -0.279 & $(0.179)$ & $-0.372 * *$ & $(0.143)$ & -0.218 & $(0.159)$ \\
\hline Bergamo & $0.573 * *$ & $(0.263)$ & 0.186 & $(0.172)$ & 0.173 & $(0.212)$ \\
\hline Padua & 0.420 & $(0.264)$ & 0.141 & $(0.187)$ & -0.007 & $(0.209)$ \\
\hline Treviso & 0.149 & $(0.187)$ & -0.226 & $(0.285)$ & -0.184 & $(0.289)$ \\
\hline Exports & $0.654 * * *$ & $(0.236)$ & $0.271^{*}$ & $(0.150)$ & 0.167 & $(0.159)$ \\
\hline Multiple commission & & & 0.057 & $(0.093)$ & -0.023 & $(0.101)$ \\
\hline \multicolumn{7}{|c|}{ PAINTER'S CHARACTERISTICS } \\
\hline Age (years) & & & & & $0.015 * * *$ & $(0.004)$ \\
\hline Balestra & & & & & $1.528 * * *$ & $(0.278)$ \\
\hline Bassano J. & & & & & 0.199 & $(0.386)$ \\
\hline Bassano F. & & & & & -0.081 & $(0.283)$ \\
\hline Cavagna & & & & & $0.644 * *$ & $(0.297)$ \\
\hline Celesti & & & & & 0.352 & $(0.321)$ \\
\hline Fumiani & & & & & $0.728 * *$ & $(0.318)$ \\
\hline Lazzarini & & & & & $0.992 * * *$ & $(0.307)$ \\
\hline Liberi & & & & & $1.393 * * *$ & $(0.315)$ \\
\hline Maffei & & & & & $0.795 * * *$ & $(0.217)$ \\
\hline Padovanino & & & & & $0.953 * *$ & $(0.379)$ \\
\hline Palma the Younger & & & & & $1.246^{* * *}$ & $(0.196)$ \\
\hline Pittoni & & & & & $1.525^{* * *}$ & $(0.389)$ \\
\hline Ricchi & & & & & $0.834 * * *$ & $(0.306)$ \\
\hline Ricci & & & & & $1.225^{* * *}$ & $(0.287)$ \\
\hline Ruschi & & & & & $1.721 * * *$ & $(0.314)$ \\
\hline Tiepolo & & & & & $1.173 * * *$ & $(0.384)$ \\
\hline Tintoretto & & & & & 0.355 & $(0.227)$ \\
\hline Titian & & & & & $0.753 * * *$ & $(0.276)$ \\
\hline Veronese & & & & & $0.656^{* *}$ & $(0.294)$ \\
\hline Zanchi & & & & & $1.186^{* * *}$ & $(0.309)$ \\
\hline Others & & & & & $0.869 * * *$ & $(0.191)$ \\
\hline
\end{tabular}


TABLE $2-$ continued

\begin{tabular}{|c|c|c|c|c|c|c|}
\hline $\begin{array}{l}\text { Independent Variables } \\
\text { OTHER }\end{array}$ & \multicolumn{2}{|l|}{ (1) } & \multicolumn{2}{|l|}{ (2) } & \multicolumn{2}{|c|}{ (3) } \\
\hline Date & & & $0.007 * * *$ & $(0.001)$ & $0.003 *$ & $(0.002)$ \\
\hline Constant term & $4.261 * * *$ & $(0.125)$ & $-8.065^{* * *}$ & $(1.277)$ & -2.609 & $(2.557)$ \\
\hline Observations & \multicolumn{2}{|l|}{254} & \multicolumn{2}{|l|}{254} & \multicolumn{2}{|c|}{254} \\
\hline$R^{2}$ & \multicolumn{2}{|l|}{0.238} & 0.669 & & \multicolumn{2}{|l|}{0.774} \\
\hline \multicolumn{7}{|c|}{$\begin{array}{l}* \text { * Significant at the } 90 \text { percent level. } \\
* *=\text { Significant at the } 95 \text { percent level. } \\
* * *=\text { Significant at the } 99 \text { percent level. } \\
\text { Notes: Robust standard errors are in parentheses. Reference categories: altar, destination }= \\
\text { Venice, Secular commissioner, painter = Farinati. }\end{array}$} \\
\hline
\end{tabular}

(for example statues, bronze decorations, tapestry, and stucco and wood works), especially in churches. Hence, the willingness to pay was lower for wall paintings than for both altarpieces and ceiling that, on the contrary, lacked feasible artistic substitutes (even frescoes were rare in Venice for problems of humidity). On the other hand, we do not find any statistically significant difference between prices of altarpieces and paintings for ceilings. ${ }^{43}$ Finally, multiple commissions were paid less, but not significantly so (partially because most were commissions of only a couple of works, rarely more than that). Finally, the final destination of the painting does not appear to affect prices. Given the economic importance of this result, we will revisit this topic in greater depth in the following subsection.

Let us move to the variables related to the painters. First of all, let us look at the artist fixed effects, introduced for all painters with at least three observations. The omitted painter is Farinati, who is the least-paid painter in the data set. The coefficients on the dummy variables show that the most famous painters as Titian and Veronese (in the late fifteenth century), Palma the Younger and Padovanino (in the seventeenth century) and Pittoni, Ricci, and Tiepolo (in the eighteenth century) commanded top prices. Other well-paid artists such as Ruschi, Balestra, Liberi, and Zanchi were well established at the time, even if less famous nowadays. An exception is Tintoretto, but this should not be entirely surprising. Tintoretto had to compete with great established masters as Titian and Veronese, and often accepted lower prices to win new commissions. Moreover, he was particularly rapid in producing

\footnotetext{
${ }^{43}$ The subjects of paintings did not affect prices and therefore we excluded the corresponding variables from the set of regressors.
} 
paintings, which allowed him to complete numerous altarpieces, huge canvases for private and public buildings (including the largest canvas in the world, the "Paradise" of Palazzo Ducale) and an impressive amount of portraits in a relatively short time. It was his speed that made it possible to accept lower prices than his rivals.

Finally, let us consider our last crucial explanatory variable, the age of execution of paintings. Our results are consistent with the hypothesis that most artists in our data set were "experimental innovators," that is painters who improved their quality over their career. The coefficient for age of painter implies an average increase in the price of paintings by around 1.5 percent per year.

\section{DESTINATION EFFECTS}

In the previous section we found that, once controlling for painting's and painter's characteristics, there is no price differential between artworks addressed to different geographical locations. In this section, we investigate further on this point in order to highlight which factors are driving the vanishing of the destination effect. The comparison of the three columns of Table 2 allows us to do this. In all three specifications, we enter a set of dummy variables for the main destinations (Verona and Vicenza, Bergamo, Padua, and Treviso), a dummy variable for the other minor provincial destinations of the Venetian Republic, and a dummy for exports. Venice is the reference group.

Results from estimating the most parsimonious price equation containing only the dummies for destination and size of paintings show that, on average, paintings addressed to small provincial centers were considerably less valued, -29 percent, than paintings produced for Venice, even controlling for size. On the contrary, we detect a positive premium for artworks addressed to Bergamo ( +57 percent) and for export sales $(+65$ percent). For the other main towns of the republic, we do not find a differential in prices per square meter with respect to Venice.

In order to see what is the role of the differences between features of paintings addressed to different destinations, in column 2 we show destinations' dummies coefficients obtained after controlling for paintings' characteristics. What we find is that the negative price differentials registered for minor centers persists, while the Bergamo coefficients is no more statistically significant. The export premium falls considerably and its statistical significance is reduced a lot, suggesting that the price differential detected before was partly due to 
the fact that exported paintings were more valuable than those produced for Venice. On the other hand, Verona and Vicenza paintings appear now less valued with respect to Venice.

These differences, however, could be due to selection of painters. Controlling for both paintings and painters' characteristics, any price differential disappears (columns 3). Indeed, minor centers as well as paintings for Verona and Vicenza were paid less because they were produced by lower-quality painters, so that when controlling for painters' quality the differential disappears. ${ }^{44}$

The conventional wisdom is thus purely an effect of selection both of paintings of different types and of painters of different skills. For instance, exported paintings were not more valuable, but foreign patrons were simply selecting higher-quality paintings by high-quality painters.

\section{THE MARKET IN CENTRAL ITALY}

The data collected by Spear and Sohm allow us to extend the analysis to the art centers of Central Italy. ${ }^{45}$ For this region, they report the original sale prices and other characteristics of 241 religious commissions traded during the Baroque period and produced by 93 artists. We separated Central Italy from the Venetian Republic because Rome, Bologna, Florence, and Naples appear to have belonged to a different integrated market in terms of artistic tradition (and therefore demand preferences) and even economic links (and therefore trade integration). Moreover, the data cover only the seventeenth century, a much shorter span than in the case of Venice, and we have fewer explanatory variables (for instance, we lack information about the planned location - altar, ceiling, or wall). Finally, the paintings in the data set refer exclusively to bargaining between artists and religious patrons (the Venetian Republic data set also included secular patrons).

The prices of paintings for each city have been converted into the local contemporary silver coins by Spear and Sohm. ${ }^{46}$ More specifically, for Rome and Florence, they are expressed in their own silver scudi, for Bologna in liras, which can be immediately converted

\footnotetext{
${ }^{44}$ A limit of our analysis is the lack of wide evidence on the paintings produced by artists active in minor towns and in the countryside. However, if price equalization did hold between heterogeneous painters arrived from everywhere to Venice and producing for different destinations, it is likely to hold also for painters producing for the same destinations outside Venice. We are grateful to the editor for pointing this out.

${ }^{45}$ Spear and Sohm, Painting for Profit.

${ }^{46}$ Ibid.
} 
TABLE 3

SUMMARY STATISTICS: CENTRAL ITALY

\begin{tabular}{|c|c|c|c|c|c|c|c|c|c|c|}
\hline \multirow[b]{2}{*}{ Variables } & \multicolumn{2}{|c|}{ All } & \multicolumn{2}{|c|}{ Rome } & \multicolumn{2}{|c|}{ Florence } & \multicolumn{2}{|c|}{ Bologna } & \multicolumn{2}{|c|}{ Naples } \\
\hline & Mean & $\begin{array}{l}\text { Std. } \\
\text { Dev. }\end{array}$ & Mean & $\begin{array}{l}\text { Std. } \\
\text { Dev. }\end{array}$ & Mean & $\begin{array}{l}\text { Std. } \\
\text { Dev. }\end{array}$ & Mean & $\begin{array}{l}\text { Std. } \\
\text { Dev. }\end{array}$ & Mean & $\begin{array}{l}\text { Std. } \\
\text { Dev. }\end{array}$ \\
\hline Price & 320.55 & 394.64 & 326.20 & 329.11 & 201.94 & 127.57 & 412.75 & 641.27 & 258.13 & 357.15 \\
\hline Size (sq. meters) & 8.95 & 7.08 & 9.06 & 8.10 & 6.90 & 2.20 & 10.39 & 6.55 & 7.99 & 4.21 \\
\hline No. of figures & 6.44 & 3.74 & 5.95 & 3.55 & 6.28 & 2.97 & 7.23 & 5.04 & 7.53 & 2.85 \\
\hline Age (years) & 43.93 & 12.70 & 43.34 & 13.52 & 47.83 & 11.92 & 43.53 & 13.17 & 44.71 & 8.79 \\
\hline Rome & 0.60 & 0.49 & - & & 一 & & 一 & & 一 & \\
\hline Florence & 0.07 & 0.26 & 一 & & 一 & & 一 & & 一 & \\
\hline Bologna & 0.17 & 0.37 & 一 & & 一 & & 一 & & 一 & \\
\hline Naples & 0.16 & 0.37 & 一 & & 一 & & - & & 一 & \\
\hline Saint Peters & 0.12 & 0.33 & & & & & & & & \\
\hline Observations & 241 & & 145 & & 18 & & 40 & & 38 & \\
\hline
\end{tabular}

Sources: Own elaboration on Spear and Sohm data.

in silver scudi, and for Naples in silver ducats. All the silver coins were exchanged almost at parity between each other, and without increasing deviations over time. However, we introduce dummies for the currencies of the four cities and a time trend to control for residual differences between average prices in different cities and for inflationary trends.

Table 3 shows some key features of the whole sample and by town. Notice that 60 percent of the paintings were from Rome, the leading art center, 17 percent from Bologna, 16 percent from Naples, and 7 percent from Florence. However, many painters were active both in Rome and in at least another of these towns (as was the case for Reni, Guercino, Domenichino, or Caravaggio). Painters received commissions at a younger age than in the Venetian Republic (44 instead of 52). ${ }^{47}$ The main explanatory variables are the same as before, including the size of paintings and the number of figures, which are smaller on average than in the Venetian Republic. Since we do not have systematic information on the positioning of the paintings (altar, wall, ceiling), we built dummies for the subjects of the paintings (including those for the presence of Christ or the Virgin in the composition, Old Testament versus New Testament stories, and

\footnotetext{
${ }^{47}$ The difference in average age between Venice and Central Italy is substantial. Notice, however, that when it is computed on the same time period in the two areas, the difference reduces to six years (50 versus 44). Moreover, there are some painters in the Venice data set, for instance Farinati or Titian, with observations at a very high age, thus contributing to increase the average age of the sample. Obviously, differences in selection are still possible.
} 
so on), which were often related to the placement of the painting in the churches. Moreover, we can classify a particular category of altarpieces, that is the altarpieces commissioned by the popes for the decoration of Saint Peter's Basilica: here a sort of efficiency wage mechanism to induce extra quality was made possible by the higher willingness to pay for quality of the popes for the major Catholic Church.

To study the relationship between destinations and the price of paintings, we relied on a conservative test. We built a dummy variable, Minor destinations, which includes all the smallest destinations different from the four main towns and the other leading art centers such as Genoa or cities outside Italy (commissions for localities in the Venetian Republic were rare). We have experimented different definitions, including only the small towns in the countryside (as in Table 2), or even larger provincial towns as Ancona, Lucca, or Perugia (all together representing 25 percent of the observations).

Regression results largely confirm the pattern found for Northern Italy (see Table 4), including a good overall fit of the model $\left(R^{2}\right.$ at 65.2 percent). Also in Central Italy the value of paintings is strongly related to their objective features; the return to size is similar to what we found for Venice (around 10.5 percent per square meter). We find again evidence of economies of scale. The number of figures is still positively related to the price, but its coefficient is much larger than for Venetian paintings: in that case we found that prices on average increased by 3 percent per figure, while now we find that each figure brings a growth in price of around 16.5 percent, though concavity is stronger (in line with a smaller average number of figures). The higher marginal impact of the number of figures is consistent with the stronger evidence of pricing per figure for Bolognese artists such as Guercino, Reni, and Domenichino, whose stylistic and contractual approach influenced the whole region, and with the larger importance of figure drawing in the artistic tradition of Central Italy compared to the priority of color in the Venetian artistic tradition. ${ }^{48}$

While differences in subjects did not affect prices in our analysis of Venice, in the case of the rest of Italy we found that when the subject of the artwork included Christ, the painting was paid 24 percent more (other subject variables were not significant). This result may depend on the correlation between this particular subject and the position of the painting in the church (for which we cannot control here): the presence of Christ was frequent in works destined for altarpieces (Crucifixion, Nativity, Virgin with Child and Saints, and so on), and for Venice we

\footnotetext{
${ }^{48}$ Ibid.
} 
TABLE 4

OLS REGRESSION: CENTRAL ITALY

Dependent variable: $\ln$ (price)

Independent Variables

\begin{tabular}{|c|c|c|}
\hline \multicolumn{3}{|c|}{ PAINTINGS' CHARACTERISTICS } \\
\hline Size (sq. meters) & $0.105 * * *$ & $(0.026)$ \\
\hline Squared size & $-0.002 * * *$ & $(0.001)$ \\
\hline No. of figures & $0.165^{* * *}$ & $(0.053)$ \\
\hline Squared no. of figures & $-0.006^{*}$ & $(0.003)$ \\
\hline Multiple commission & $-0.462 * * *$ & $(0.146)$ \\
\hline Christ & $0.236 * *$ & $(0.111)$ \\
\hline Florence & -0.024 & $(0.178)$ \\
\hline Naples & 0.022 & $(0.213)$ \\
\hline Bologna & -0.005 & $(0.212)$ \\
\hline Saint Peter & $0.534 * * *$ & $(0.185)$ \\
\hline Minor destination & 0.088 & $(0.147)$ \\
\hline \multicolumn{3}{|c|}{ PAINTER'S CHARACTERISTICS } \\
\hline Age (years) & $0.090 * * *$ & $(0.028)$ \\
\hline Squared age & $-0.001 * *$ & $(0.000)$ \\
\hline Sacchi & $0.893 * * *$ & $(0.246)$ \\
\hline Baglione & $0.786 * * *$ & $(0.301)$ \\
\hline Caravaggio & $0.630 * *$ & $(0.255)$ \\
\hline Carracci L. & $-0.671 * *$ & $(0.284)$ \\
\hline Cortona & $0.717 * * *$ & $(0.206)$ \\
\hline Domenichino & $0.713 * *$ & $(0.314)$ \\
\hline Gaulli & 0.266 & $(0.198)$ \\
\hline Gimignani G. & $-0.320^{*}$ & $(0.178)$ \\
\hline Maratta & $0.819 * * *$ & $(0.240)$ \\
\hline Passignano & 0.421 & $(0.298)$ \\
\hline Reni & $0.554^{*}$ & $(0.291)$ \\
\hline Others & -0.031 & $(0.222)$ \\
\hline \multicolumn{3}{|l|}{ OTHER } \\
\hline Date & 0.001 & $(0.003)$ \\
\hline Constant & -0.920 & $(5.514)$ \\
\hline Observations & 241 & \\
\hline$R^{2}$ & 0.652 & \\
\hline
\end{tabular}

* = Significant at the 90 percent level.

** = Significant at the 95 percent level.

$* * *=$ Significant at the 99 percent level.

Notes: Robust standard errors are in parentheses. Reference categories: subject $=$ different from Christ, destination $=$ Rome, painter $=$ Trevisani. The coefficients for other painters that were statistically significant are not reported (Arpino, Caracciolo, Giordano, Lanfranco, Preti, Romanelli, Roncalli, Rosselli, and Tiarini). 
found that altarpieces were indeed paid more. While we do not have paintings for public buildings, our data set includes a few altarpieces destined to Saint Peter's Church: not surprisingly, these altarpieces were much more valuable than average. The fact that the painting was part of a multiple commission of religious paintings in this case affects prices: the coefficient is now negative and statistically significant.

Let us turn to the destination effects. Again, we find little evidence of differences between prices of different sites. The destinations' coefficients are not significant, and the paintings destined to minor localities (here defined as minor provincial towns in the countryside) are not paid less than those destined to the major cities, at least after controlling for all the features of paintings and painters. Again, trade in paintings within an integrated market appears sufficient to equalize prices between different destinations.

Last, we move to the painters' specific variables. As to artist fixed effects, Trevisani, the least-paid painter, is the omitted category. The most famous figurative artists of the Baroque age, such as Cortona, Sacchi, and Maratta appear to be the best-paid artists of the time, followed by Caravaggio (at the time less appreciated than nowadays) and Bolognese masters such as Reni and Domenichino.

\section{THE GALENSON HYPOTHESIS}

The positive relation between age of painters and price of paintings previously ascertained for Venetian art is even stronger in Central Italy, as suggested by the larger coefficient of age ( 9 percent a year). This is not surprising given the difference in average age between the two areas. In this case, we also observe slightly decreasing returns to age. Figure 1 describes the age-price profile by plotting the residuals obtained after regressing the logarithm of price over all explanatory variables included in the regression in Table 4 with the exception of age and its square. The figure confirms that the prices of paintings increased until about the age of 62 and it started to decrease afterwards. ${ }^{49}$

Therefore, the estimates suggest that the Baroque age included many artists who developed their skills through experience and reached their best production at a late age, the experimental innovators of Galenson.

\footnotetext{
${ }^{49}$ We estimated the price equation also by using a set of 10 -year dummies and results (available from the author upon request) show that prices increase monotonically during artistic life but they start decreasing in the very final part of the career.
} 


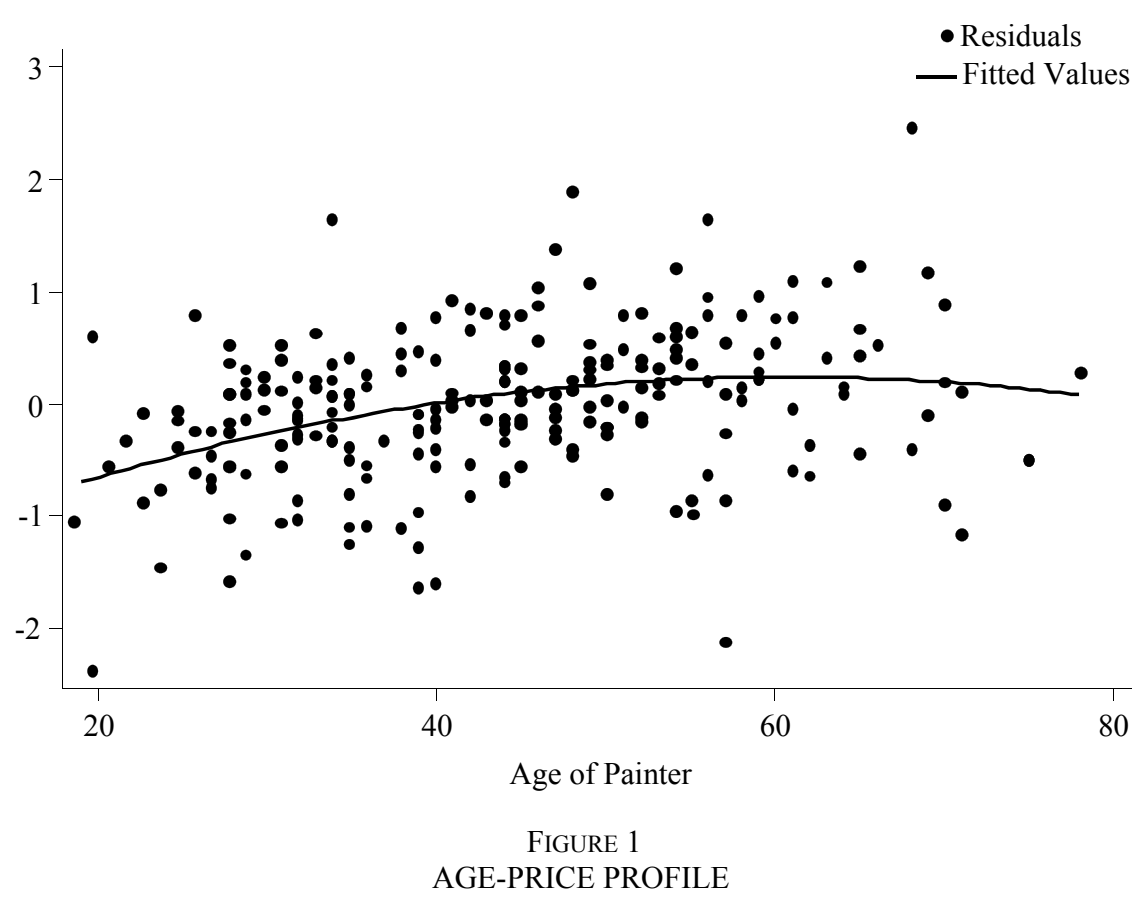

Sources: Own elaboration on Spear and Sohm data.

Bearing in mind that we have just few observations per painter and that they do not cover whole painters' artistic career, Figure 2 reports the life cycle of the price per square meter for some famous and high-quality painters of different generations: Tintoretto and Ricci from Venice and Reni and Domenichino from Bologna. With the before mentioned caveat in mind, the figure suggests for all of them a discernible increasing path of the normalized price of paintings. Most interestingly, all of them could be seen as belonging to the category of experimental painters in the Galenson's terminology. Leaving additional investigations for art historical research and recalling that we are just trying to present some evocative evidence, we can add a few remarks on the careers of some of these painters.

The mannerist painter Tintoretto developed his style over time: he completed one of his masterpieces, the Last Supper (S. Giorgio Maggiore, Venice), in the last year of his life when he was seventy-six. Concerning the Rococò painter Ricci, a leading expert of Venetian art talks about a sviluppo lento (slow development) of his style: ${ }^{50}$ the majority of his works, and all the most famous ones are posterior

\footnotetext{
${ }^{50}$ See Pallucchini, Pittura Veneziana.
} 

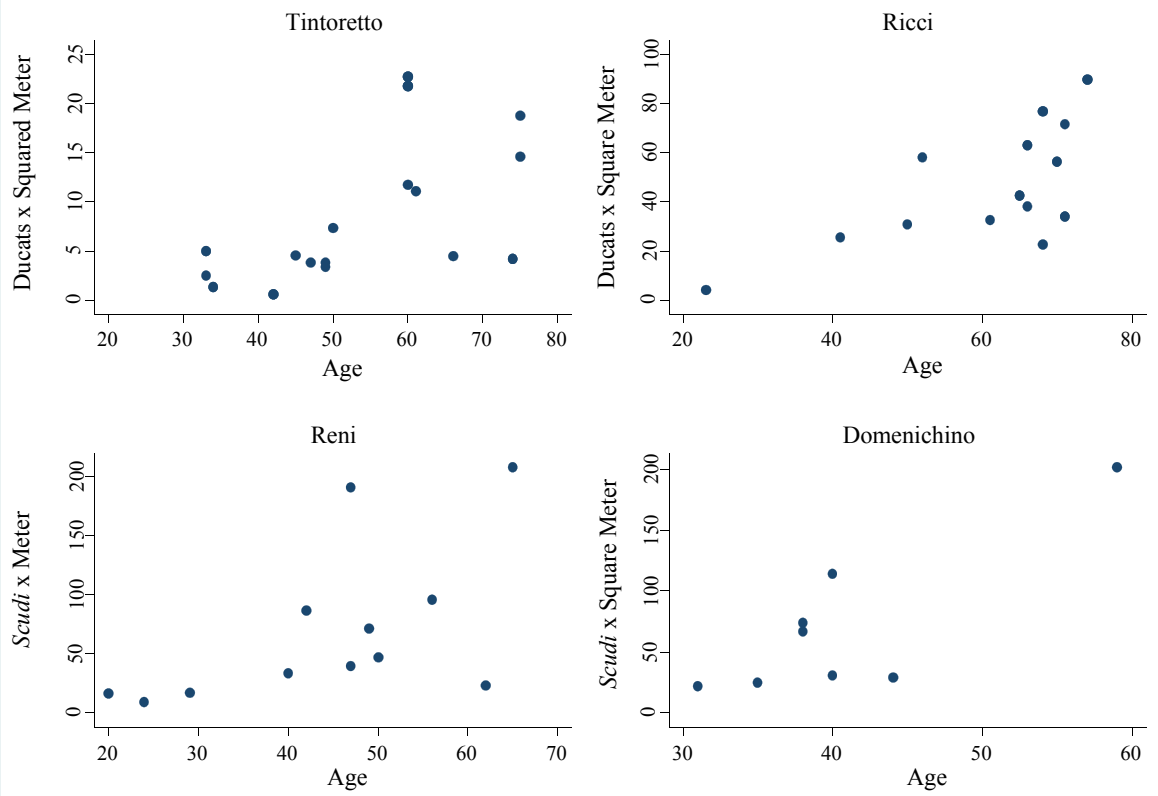

FIGURE 2

AGE-PRICE PROFILE FOR SELECTED TOP-QUALITY PAINTERS

Sources: Own elaboration on Spear and Sohm data.

to 1700 (when he was more than forty), which clearly points toward experimentalism in the sense of Galenson. Also, the two leading Bolognese Baroque painters active in Central Italy experienced a deep and long evolution toward an ideal classicism which led them to increasing fame and appreciation. Guido Reni reached his maturity when back in Bologna after more than a decade spent in Rome (and the initial apprenticeship in Bologna). His own words may be the best witnesses of his constant experimentalism: "the most beautiful painting is the one I am doing, and if tomorrow I will do another, it will be that one." Domenichino improved his style in a long activity in Rome, but he reached his maximum achievements in the last decade of his life, almost entirely dedicated to the frescoes for the Cathedral of Naples. $^{51}$

Caravaggio followed a completely different path. He moved from Milan to Rome without much experience. Forsaking the mannerist style of his initial master Arpino (celebrated and well paid at the time, virtually forgotten today), he approached painting from a new and different perspective. Caravaggio was revolutionary in many ways:

${ }^{51}$ See Spear and Sohm, Painting for Profit. 


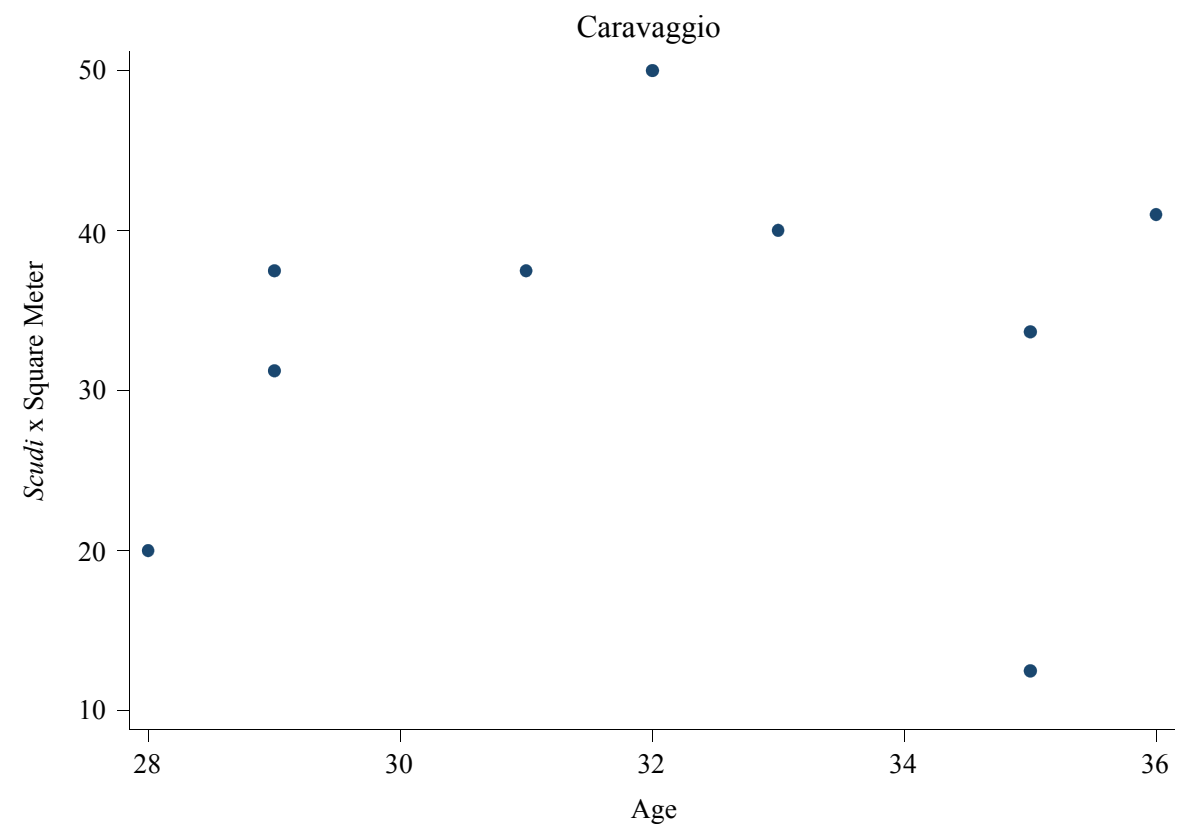

FIGURE 3

AGE-PRICE PROFILE FOR A CONCEPTUAL INNOVATOR

Sources: Own elaboration on Spear and Sohm data.

he introduced new subjects as still lifes (reproducing mainly lifeless objects) and genre paintings (reproducing daily life scenes); he adopted a new way to bring external light into the pictures, and pursued extreme realism beyond what anyone had ever done. All of these innovations emerged immediately in his early works during his twenties, as in the famous still life of the "Basket of Fruits" (Pinacoteca Ambrosiana, Milan) and the "Fortune Teller" (Louvre, Paris) executed when about twenty-five, or in famous altarpieces as "The Calling of St. Matthew" (S. Luigi dei Francesi, Rome), executed at the age of twenty-eight. His later works are considered equally valuable, but less innovative. Even looking at Caravaggio's compensations, we do not find any increasing pattern with age. Besides being moderately priced from the beginning, Caravaggio was not perceived as improving his quality or innovating during his later career. Figure 3 shows the price per square meter of his altarpieces included in our data set: if anything, the erratic path is in line with the hypothesis that we are in front of a conceptual innovator in the terminology of Galenson. ${ }^{52}$

\footnotetext{
${ }^{52}$ Also in this case some caution is needed as Caravaggio died when he was almost 40, so his career path is rather impossible for us to infer.
} 


\section{CONCLUSION}

We have studied the Italian market for oil paintings of historical subject during the Baroque era through econometric analysis of a unique data set containing the prices derived from the original contracts. Our main purpose was to show that looking at the market for paintings as a fully fledged market could shed light on the determination of the prices of some of the most valuable handmade objects of humankind. The market for oil paintings was extremely competitive and populated by players very similar to what we may now define as representatives of the homo economicus. They developed forms of horizontal and vertical differentiation which created separate markets where demand and supply conditions clearly affected equilibrium prices. ${ }^{53}$ They solved contractual problems between patrons (principals) and artists (agents) as we would expect in the presence of unverifiable quality and moral hazard: conditioning payments on measurable variables related to quality, as the number of figures depicted. And they exploited their experience to innovate and increase their market power. Moreover, there was sufficient trade in paintings to equalize prices across different destinations.

In a celebrated historical account of the demand for art in the Renaissance period, Richard A. Goldthwaite has pointed out that Italian cities have generated the first modern markets for durable luxury goods, which have been at the origins of modern capitalism based on consumerism. "Today the consumer instinct is taken for granted: the challenge to producers is to introduce new products, reduce prices, and change fashion... If, on the one hand, we decry what this consumerism has developed into in our own times, with its commodity culture of planned obsolescence, throwaway goods, and fashion-ridden boutiques, on the other hand, we have enshrined its very spirit in our great museums. These veritable temples to the consumption habits of the past, where we worship as art one of the dynamics that gives life to the economic system of the West, mark the supreme achievement of capitalism." ${ }^{, 5}$ The market for paintings in the sixteenth-seventeenth century is not only one of the first markets for durable luxury goods of the modern capitalistic society. Its surviving documentary evidence and even its surviving products are witnesses that it was also one of the first markets to follow the main laws of economics and rational market behavior.

\footnotetext{
${ }^{53}$ The role of genre differentiation in the market for paintings remains a crucial aspect to study.

${ }^{54}$ Goldthwaite, Wealth and the Demand, pp. 253-54.
} 


\section{REFERENCES}

Clark, Gregory. "The Cost of Capital and Medieval Agricultural Technique." Explorations in Economic History 25, no. 3 (1988): 265-94.

De Marchi, Neil. "The Role of Dutch Auctions and Lotteries in Shaping the Art Market(s) of Seventeenth-Century Holland." Journal of Economic Behavior \& Organization 28, no. 2 (1995): 203-21.

Etro, Federico, and Laura Pagani. "The Market for Paintings in the Venetian Republic, 1550-1750." Mimeo, University of Venice Ca' Foscari, Venice, December 2010.

Favaro, Elena. L'arte dei Pittori in Venezia e i suoi Statuti. Firenze: Olschki, 1975.

Galenson, David W. Old Masters and Young Geniuses: The Two Life Cycles of Artistic Creativity. Princeton, NJ: Princeton University Press, 2006.

Galenson, David W., and Robert Jensen. "Young Geniuses and Old Masters: The Life Cycles of Great Artists from Masaccio to Jasper Johns." NBER Working Paper No. 8368, Cambridge, MA, July 2001.

Galenson, David W. and Bruce, A. Weinberg. "Age and the Quality of Work: The Case of Modern American Painters." Journal of Political Economy 108, no. 4 (2000): 761-77.

Gérin-Jean, Pierre. "Prices of Works of Art and Hierarchy of Artistic Value on the Italian Market (1400-1700)." In The Art Market in Italy, edited by M. Fantoni, L. C. Matthew, and S. F. Matthews-Grieco, 181-94. Ferrara: Panini, 2003.

Goldthwaite, Richard A. Wealth and the Demand for Art in Italy, 1300-1600. Baltimore, MD: John Hopkins University Press, 1993.

Hauser, Arnold. The Social History of Art. London: Routledge, 1951.

Hellmanzik, Christiane. "Location Matters: Estimating Cluster Premiums for Prominent Modern Artists." European Economic Review 54, no. 2 (2010): 199-218.

Holmstrom, Bengt. "Moral Hazard and Observability." Bell Journal of Economics 10, no. 1 (1979): 74-91.

Malanima, Paolo. L'Economia Italiana. Dalla Crescita Medievale alla Crescita Contemporanea. Bologna: Il Mulino, 2002.

Martini, Angelo. Manuale di Metrologia, ossia Misure, Pesi e Monete in Uso Attualmente e Anticamente presso tutti i Popoli. Torino: Loescher, 1883.

McCloskey, Donald N., and John Nash. "Corn at Interest: The Extent and Cost of Grain Storage in Medieval England." American Economic Review 74, no. 1 (1984): 174-87.

Montias, John M. Art at Auction in Seventeenth-Century Amsterdam. Amsterdam: Amsterdam University Press, 2002.

Nelson, Jonathan K., and Richard Zeckhauser. The Patron's Payoff: Conspicuous Commission in Italian Renaisssance Art. Princeton, NJ: Princeton University Press, 2008.

North, Michael. Art and Commerce in the Dutch Golden Age. New Haven, CT: Yale University Press, 1999.

O'Rourke, Kevin H., and Jeffrey G. Williamson. Globalization and History: The Evolution of a Ninenteenth-Century Atlantic Economy. Cambridge, MA: MIT Press, 1999.

O'Malley, Michelle. The Business of Art: Contracts and the Commissioning Process in Renaissance Italy. New Haven, CT: Yale University Press, 2005.

Rönnbäck, Klas. "Integration of Global Commodity Markets in the Early Modern Era." European Review of Economic History 13, no. 1 (2009): 95-120.

Spear, Richard E., and Philip L. Sohm. Painting for Profit: The Economic Lives of Seventeenth-Century Italian Painters. New Haven, CT: Yale University Press, 2010. 